west of Scotland (Scottish Committee Action on Smoking and Health, personal communication). There are two likely reasons for this difference: firstly, the habit forming nature of cigarette smoking probably makes it easier for the average person to stop drinking rather than to stop smoking, and, secondly, the risks of the fetal alcohol syndrome have been widely publicised, particularly in the west of Scotland.

Little is known about clinical pharmacology during pregnancy. A survey of this type can identify those drugs that are most commonly used, highlighting where further research into safety and efficacy might appropriately be pursued. The limited available knowledge on the disposition of drugs during pregnancy indicates that in some instances, such as the use of anticonvulsants, substantial and clinically important changes require an approach to prescribing quite different from that in non-obstetric practice. A knowledge of those drugs most often used allows direction of research into clinical pharmacokinetics during pregnancy. There is virtually no available information on whether pregnancy influences the effect of drugs, and yet a typical obstetric unit can expect to see an average of two new patients each week who are receiving a drug such as a bronchodilator, $\beta$ blocker, or anticonvulsant, the effect of which could, theoretically, be influenced by the physiological changes of pregnancy. An additional point to emerge from studies of this type is the question of whether the drugs used were really necessary. This, of course, is a matter not confined to pregnancy, but the lists given earlier suggest that the mother's health would not have been put at risk if some of the more commonly used groups of drugs were withheld.

In conclusion, we have described the pattern of use of drugs in a general obstetric unit in Glasgow during the mid-1980s. Most women did not take drugs or drink alcohol, but the extent of cigarette smoking, the use of self administered analgesics, and the relatively common administration of drugs clearly not necessary for maternal health are matters worthy of further attention.

We thank Dr C J Bulpitt for advice in planning these studies, Dr M De Swiet for critical review of the manuscript, and the obstetricians at this hospital for allowing us to study their patients.

\section{References}

1 Mellin GW, Katzenstein M. The saga of thalidomide. N Engl f Med 1962;267:1184-92, 1238-44. 2 Hayman DJ. Withdrawal of thalidomide. BrMed $\mathcal{F} 1961$; iv: 1499

Kullander S, Kallen B. A prospective study of drugs and pregnancy. Acta Obstet Gynecol Scand 1976;55:287-95.

4 Forfar JO, Nelson MM. Epidemiology of drugs taken by pregnant women: drugs that may affect the fetus adversely. Clin Pharmacol Ther 1973;14:632-42.

5 Peckham $\mathrm{CH}$, King RW. A study of intercurrent conditions observed during pregnancy. $A m \mathcal{F}$ Obstet Gynecol 1963;87:609-20.

6 Heinonen OP, Slone D, Shapiro S. Birth defects and drugs in pregnancy. Littleton, Massachusetts: Publishing Sciences Group, 1977.

7 Brocklebank JC, Ray WA, Federspiel CF, Schaffner W. Drug prescribing during pregnancy. Am f Obstet Gynecol 1978;132:235-44

8 Dixon WJ, ed. BMDP statistical software. California: University of California Press, 1983

8 Dixon WJ, ed. BMDP statistical software. California: University of California Press, 1983. formulary No 9. London: British Medical Association and the Pharmaceutical Society of Great formulary No 9. London: British Medical Association and the Pharmaceutical Society of Great
Britain, 1985.

10 Nelson MM, Forfar JO. Association between drugs administered during pregnancy and congenital abnormalities of the fetus. Br Med f 1971;i:523-7.

$11 \mathrm{McNeil}$ JR. The possible teratogenic effect of salicylates on the developing fetus. Clin Pediatr (Phila) 1973;12:347-50.

12 Richards ID. Congenital malformations and environmental influences in pregnancy. $\mathrm{Br} f \operatorname{Prev~Soc}$ Med 1969;23:218-25.

13 Slone D, Suskind V, Heinonen OP. Aspirin and congenital malformations. Lancet 1976;i:1373-5. 14 Turner G, Collins E. Fetal effects of regular salicylate ingestion in pregnancy. Lancet 1975;ii: 338-9.

15 Stuart MJ, Gross SJ, Elrad H, Graeber JE. Effects of acetylsalicylic acid ingestion on maternal and neonatal hemostasis. N Engl f Med 1982;307:909-12.

16 Perkin RM, Levin D, Clark D. Serum salicylate levels and right to left ductus shunt in newborn infants with persistent pulmonary hypertension. $\mathcal{F}$ Pediatr 1980;96:721-6.

\title{
Intermittent clinical proteinuria and renal function in diabetes: evolution and the effect of glycaemic control
}

\author{
J J BENDIIJG，G C VIBERTI，P J WATKINS， H KEEN
}

\begin{abstract}
The evolution of renal disease was studied in 12 insulin dependent diabetics selected for intermittent clinical proteinuria. After a run in period during which patients were studied three monthly for at least 12 months members of pairs of patients matched for age and duration of diabetes were allocated either to receive continuous subcutaneous insulin infusion or to continue with their usual conventional insulin injection therapy (controls) and studied three monthly for a further year. Mean (SEM) plasma glucose concentration and glycosylated haemoglobin $\left(\mathbf{H b A}_{1}\right)$ value improved significantly in the insulin infusion group (glucose 10.1 (1.0) v 5.3(0.3) $\mathrm{mmol} / 1$ (182 (18) v $95(5) \mathrm{mg} / 100 \mathrm{ml}$ );
\end{abstract}

\footnotetext{
Unit for Metabolic Medicine, United Medical and Dental Schools (Guy's Campus), London SE1 9RT

J J BENDING, MD, MRCP, Wolfson research fellow and honorary senior registrar GC VIBERTI, MD, MRCP, senior lecturer and honorary consultant

H KEEN, MD, FRCP, professor of human metabolism
}

Diabetic Clinic, King's College Hospital, London SE5 9RS

P J WATKINS, MD, FRCP, consultant physician

Correspondence and requests for reprints to: Dr Viberti.
$\mathrm{HbA}_{1} 9.6(0.8) v 7.6(0.5) \% ; \mathbf{p}<0.001$ and $\mathbf{p}<0.005$, run in $v$ experimental periods) but not in the control group. Blood pressure was kept normal throughout.

Glomerular filtration rate fell significantly in the insulin infusion and control groups throughout the study, from mean (SEM) baseline values of $114(16)$ and $119(15) \mathrm{ml} / \mathrm{min} / 1.73 \mathrm{~m}^{2}$ to final values of $92(15)$ and $95(13) \mathrm{ml} / \mathrm{min} / 1.73 \mathrm{~m}^{2}$ respectively $(p<0.05$ and $p<0.01)$. The mean rate of decline in glomerular filtration rate did not change significantly in either group (run in $v$ experimental periods: insulin infusion group $1.0 v 0.8 \mathrm{ml} / \mathrm{min} /$ month; controls $0.8 v 0.9 \mathrm{ml} / \mathrm{min} /$ month). Mean (SEM) plasma creatinine concentration rose slightly in the insulin infusion group only (93 (5) to $107(11) \mu \mathrm{mol} / 1(1.1(0.06)$ to $1.2(0.1) \mathrm{mg} /$ $100 \mathrm{ml}), 0.1>$ p $>0.05$; controls $94(6)$ to $96(6) \mu \mathrm{mol} / 1(1.1(0.07)$ and $1.1(0.07) \mathrm{mg} / 100 \mathrm{ml})$ ). The urinary excretion rate of albumin varied widely and unpredictably throughout, while $\beta_{2}$ microglobulin excretion remained normal and unchanged in both groups.

Thus (a) at the stage of intermittent clinical proteinuria when albumin excretion rate is unpredictably variable (breaking through the "clinically positive" threshold only episodically) renal function, though still in the "normal" range, is already declining progressively; and (b) the study failed to show that sustained improvement in mean glycaemia exerts a significant effect on this early deterioration of renal function. 


\section{Introduction}

Intermittent clinical (Albustix positive) proteinuria in insulin dependent diabetes mellitus is a phase usually succeeded by persistent proteinuria in the evolution of diabetic nephropathy. ${ }^{12}$ The state of glomerular function and its change over time in this phase, however, are largely unknown. Watkins et al reviewed renal biopsy samples from 31 proteinuric diabetic patients taken 11 years previously ${ }^{3}$ in order to determine the course of diabetic renal disease. Two of these patients had experienced no significant decline in renal function (on the basis of serum creatinine estimations) after more than 12 years of intermittent proteinuria and a duration of diabetes of 22 and 23 years. Mogensen described a group of patients with intermittent proteinuria shown by Albustix testing as "nearly always having a highly elevated albumin excretion in the basal situation," with values of albumin excretion ranging from normal at about $6 \mu \mathrm{g} / \mathrm{min}$ to some $200 \mu \mathrm{g} / \mathrm{min} .{ }^{4}$ Their glomerular filtration rates were significantly higher than normal and did not decline over three to four years. ${ }^{5} \mathrm{He}$ also concluded that transition from normal albumin excretion to persistent clinical proteinuria occurs rapidly.

In a small group of patients we have made a detailed prospective examination of the relation of intermittent clinical proteinuria to renal function in insulin dependent diabetes mellitus and the effect of glycaemic control.

\section{Patients and methods}

We defined intermittent clinical proteinuria as repeated Albustix tests (one plus or more) of sterile urine positive on no more than two consecutive occasions over a period of observation of at least one year during which a minimum of four tests were made. The study was restricted to patients aged assigned to treatment with continuous subcutaneous insulin infusion and the other to continue unchanged with conventional injection therapy. This was followed by an experimental period of 12 months with assessments every three months. Table I shows the clinical features of the two groups.

TABLE I-Clinical characteristics of patients studied

\begin{tabular}{|c|c|c|}
\hline & \multicolumn{2}{|c|}{ Treatment group } \\
\hline & $\begin{array}{l}\text { Conventional insulin } \\
\text { injection therapy }\end{array}$ & $\begin{array}{l}\text { Continuous subcutaneous } \\
\text { insulin infusion }\end{array}$ \\
\hline $\begin{array}{l}\text { No of patients } \\
\text { Mean age (years) (range) } \\
\text { Mean duration of diabetes } \\
\text { (years) (range) } \\
\text { Complications }\end{array}$ & $\begin{array}{l}5 \mathrm{M}, 1 \mathrm{~F} \\
35 \cdot 8(26-58) \\
19 \cdot 3(11-28) \\
3 \mathrm{NPR}, 3 \mathrm{PR}, 4 \mathrm{PN}, 2 \mathrm{AN}\end{array}$ & $\begin{array}{l}22 \cdot 2(18-28) \\
3 \mathrm{NPR}, 3 \mathrm{PR}, 1 \mathrm{PN}, 3 \mathrm{AN}\end{array}$ \\
\hline
\end{tabular}

$\star N P R=$ Non-proliferative retinopathy. $P R=$ Proliferative retinopathy. $P N=$ Peripheral neuropathy. AN=Autonomic neuropathy.

Assessments were made during a 24 hour admission to a metabolic ward, when the following measurements were made: two-hourly plasma glucose profile (Yellow Springs analyser, Yellow Springs, USA); fasting glycosylated haemoglobin $\left(\mathrm{HbA}_{1}\right)$ concentration (isoelectric focusing method ${ }^{6}$ ); glomerular filtration rate (clearance of chromium-51 labelled edetic acid $\left.{ }^{7}\right)$ corrected to $1.73 \mathrm{~m}^{2}$ of surface area; plasma creatinine and albumin concentrations; 24 hour urine collection for albumin and $\beta_{2}$ microglobulin excretion rates $^{8}$; microscopy and culture of a clean midstream urine collection. Right brachial arterial pressure was measured by the same observer four times with the patient lying and standing using a standard mercury sphygmomanometer during each visit. Mean arterial pressure was calculated as the sum of the diastolic pressure plus one third of the pulse
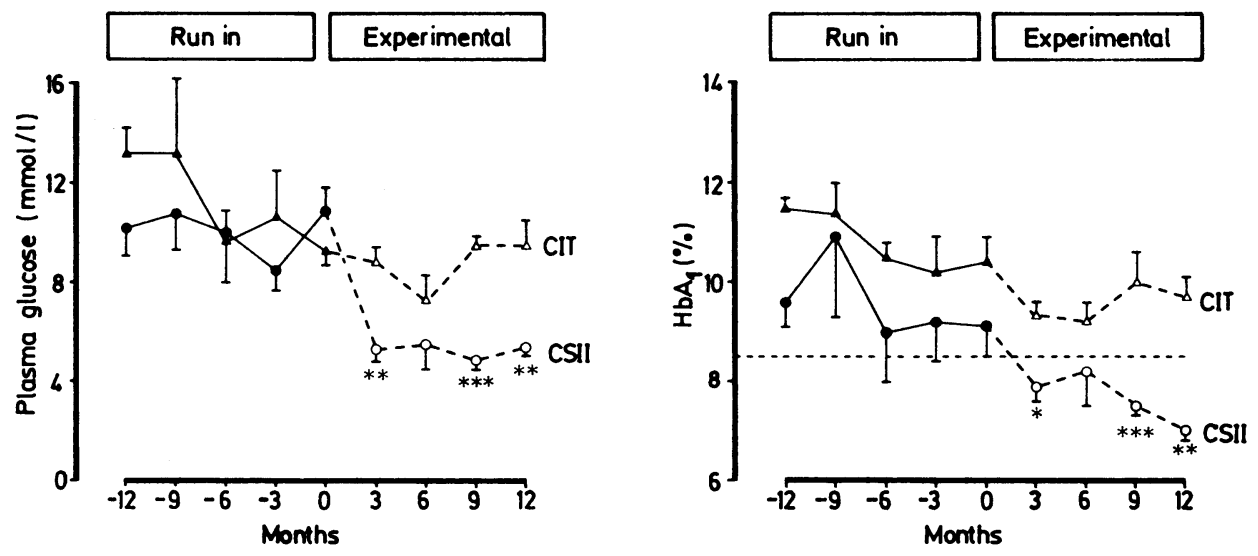

FIG 1-Mean (and SEM) plasma glucose concentrations and glycosylated haemoglobin $\left(\mathbf{H b} \mathbf{A}_{1}\right)$ values in six insulin dependent diabetic patients with intermittent clinical proteinuria before $(\bullet-\bullet)$ and after $(0 \ldots 0)$ random allocation to receive continuous subcutaneous insulin infusion (CSII) and in six insulin dependent diabetic patients with intermittent clinical proteinuria before $(\Delta-\Delta)$ and after $(\Delta--\Delta)$ random allocation to continue with conventional insulin injection therapy (CIT). Horizontal dashed line represents upper limit of normal for $\mathrm{HbA}_{1}$ value (see text).

Compared with CIT: ${ }^{\star} p<0.02 ;{ }^{\star} p<0.005 ;{ }^{\star \star \star} \mathrm{p}<0.001$.

Conversion: SI to traditional units_Glucose: $1 \mathrm{mmol} / 1 \approx 18 \mathrm{mg} / 100 \mathrm{ml}$

under 55 with a duration of diabetes of at least 10 years and with ophthalmoscopically evident diabetic retinopathy. Insulin dependent patients who fulfilled these criteria and were without evidence of nondiabetic renal disease were recruited from the diabetic clinics of Guy's Hospital and King's College Hospital, London. All gave informed consent to the study, which was approved by the Guy's Hospital ethical committee.

\section{STUDY DESIGN}

After a run in period with assessments every three months for at least a year in order to obtain stable baseline data the patients were paired by closest matching for age, sex, and duration of diabetes. One member was randomly pressure. The mean of the four measurements was used for calculation. Arterial pressure was maintained below $160 / 90 \mathrm{~mm} \mathrm{Hg}$ throughout; two patients in each group received antihypertensive medication. Initiation and long term outpatient follow up of continuous subcutaneous insulin infusion was as described..$^{10}$ No dietary change was recommended. Protein intake was similar in the two groups and remained unchanged during the study, being on average $79 \cdot 8$ (SD 20.7) g/day.

Statistical evaluation was by analysis of covariance for comparison of slopes of regression lines and Student's $t$ test for paired and unpaired samples. The relation between absolute values of glomerular filtration rate at the beginning and end of the study and changes in rate during the study to absolute values and changes in blood pressure, plasma glucose concentration, $\mathrm{HbA}_{1}$ value, and fractional clearance of albumin were evaluated by univariate regression analysis. Values for albumin and $\beta_{2}$ microglobulin 
excretion rates were log transformed because of their skewed distributions. The $95 \%$ confidence limits for changes in glomerular filtration rate and albumin excretion were calculated.

\section{Results}

Figure 1 shows the mean plasma glucose concentrations and $\mathrm{HbA}_{1}$ values for both groups during the run in and experimental phases of the study. Some improvement in glycaemic control in patients who continued with their conventional injection therapy was noted during the run in phase. A non-significant fall in mean blood glucose concentration six months after entering the experimental phase was not sustained. In the insulin infusion treated patients the mean plasma glucose concentration at most time points during the experimental phase of the study was significantly lower than that of the control group and approached normoglycaemia. During the experimental phase $\mathrm{HbA}_{1}$ values were unchanged in the controls but fell significantly in the insulin infusion group, by 12 months entering our normal range $(5 \cdot 5-7 \cdot 5 \%$, two standard deviations from the mean of 100 non-diabetic subjects).

Figure 2 shows the change with time of the mean glomerular filtration rate values for each group. Although rates were all still in the normal range, there was a significant decline in rates in both the control and insulin infusion groups throughout the entire study (controls 119 (SEM 15) $\mathrm{ml} / \mathrm{min} / 1.73 \mathrm{~m}^{2}$ to 95 (13) $\mathrm{ml} / \mathrm{min} / 1.73 \mathrm{~m}^{2}(\mathrm{p}<0.05)$; insulin infusion group 114 (SEM 16) $\mathrm{ml} / \mathrm{min} / 1.73 \mathrm{~m}^{2}$ to $\left.92(15) \mathrm{ml} / \mathrm{min} / 1.73 \mathrm{~m}^{2}(\mathrm{p}<0.01)\right)$. The decline in glomerular filtration rate continued in the infusion group during the experimental period despite the substantial, significant, and sustained fall in mean glycaemia. In the control group the decline in glomerular filtration rate during the experimental phase was $0.9 \mathrm{ml} / \mathrm{min} / \mathrm{month}$, hardly differing from the decrement of $0.8 \mathrm{ml} / \mathrm{min} /$ month noted during the run in phase. Similarly, a fall in the glomerular filtration rate during the experimental phase of $0.8 \mathrm{ml} / \mathrm{min} / \mathrm{month}$ did not differ significantly from that of $1.0 \mathrm{ml} /$ $\mathrm{min} / \mathrm{month}$ in the run in phase in the insulin infusion group. The $95 \%$ confidence limits of the mean of the differences between the two treatment periods (insulin infusion group $-0.1 \mathrm{ml} / \mathrm{min} / \mathrm{month}$; control group $+0.5 \mathrm{ml} / \mathrm{min} / \mathrm{month}$ ) ranged from -0.99 to $+0.78 \mathrm{ml} / \mathrm{min} / \mathrm{month}$ (insulin

TABLE II-Glomerular filtration rates $\left(\mathrm{ml} / \mathrm{min} / 1.73 \mathrm{~m}^{2}\right)$ for each patient with intermittent clinical proteinuria at beginning and end of run in and experimental periods of study

\begin{tabular}{|c|c|c|c|c|c|c|c|c|c|c|c|c|c|c|}
\hline \multirow[b]{2}{*}{ Time in months } & \multicolumn{7}{|c|}{ Cases treated by conventional insulin injection therapy } & \multicolumn{7}{|c|}{ Cases treated by continuous subcutaneous insulin infusion } \\
\hline & 1 & 2 & 3 & 4 & 5 & 6 & Mean (SEM) & 7 & 8 & 9 & 10 & 11 & 12 & Mean (SEM) \\
\hline-12 & 78 & 130 & 99 & 182 & 132 & 95 & $119(15)$ & 65 & 133 & 99 & 82 & 145 & 162 & $114(16)$ \\
\hline 0 & 68 & 117 & 116 & 171 & 111 & 78 & 110 (15) & 59 & 126 & 93 & 78 & 145 & 125 & 104 (13) \\
\hline+12 & 53 & 98 & 103 & 148 & 101 & 68 & $95(13)$ & 45 & 111 & 67 & 75 & 149 & 105 & $92(15)$ \\
\hline
\end{tabular}
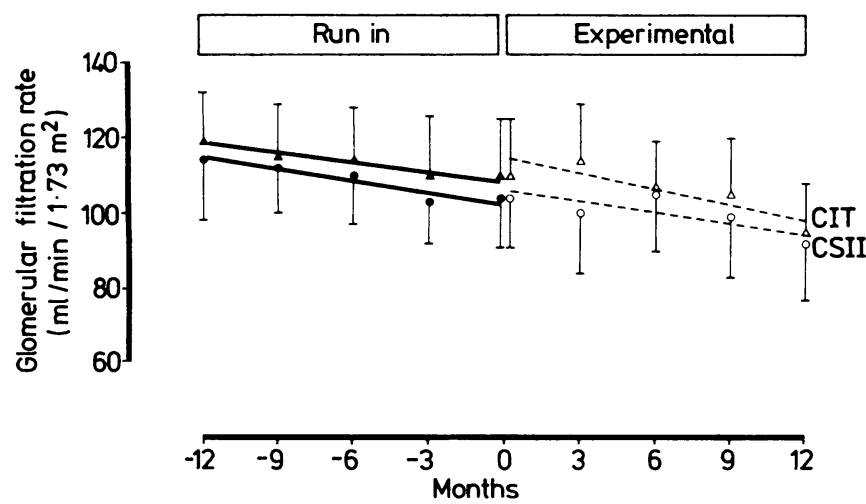

FIG 2-Calculated slopes of mean (and SEM) glomerular filtration rates in patients with intermittent clinical proteinuria before and after random allocation either to receive continuous subcutaneous insulin infusion (CSII) or to continue with conventional insulin injection therapy (CIT). Symbols as in fig 1 .
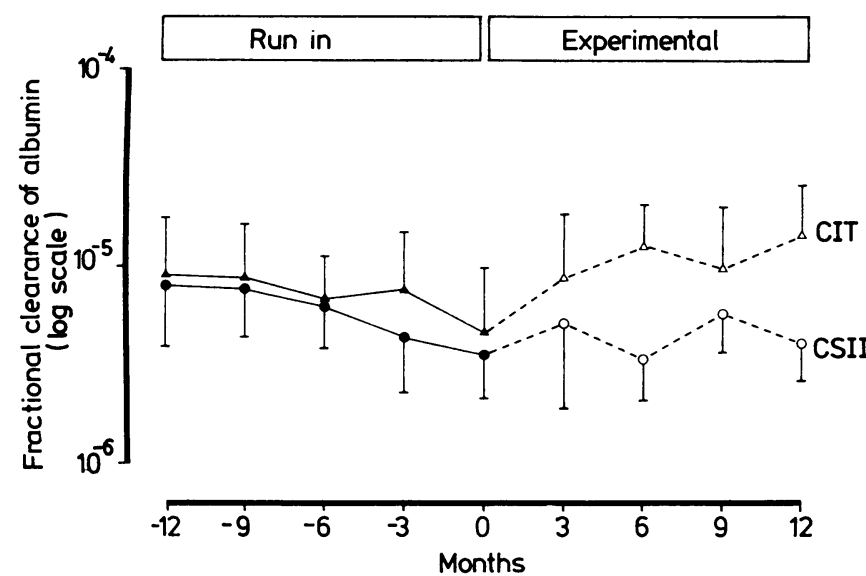

FIG 3-Mean (and SEM) fractional clearances of albumin (log scale) in patients with intermittent clinical proteinuria before and after random allocation to either continuous subcutaneous insulin infusion (CSII) or unchanged conventional insulin injection therapy (CIT). Symbols as in fig 1 .
TABLE III-Albumin excretion rates ( $\mu \mathrm{g} / \mathrm{min})$ for 12 insulin dependent diabetic patients with intermittent clinical proteinuria studied at three month intervals during run in and experimental phases of study

\begin{tabular}{|c|c|c|c|c|c|c|c|c|c|}
\hline \multirow[b]{2}{*}{ Case No } & \multicolumn{5}{|c|}{ Run in period (months) } & \multicolumn{4}{|c|}{ Experimental period (months) } \\
\hline & -12 & -9 & -6 & -3 & 0 & 3 & 6 & 9 & 12 \\
\hline \multicolumn{10}{|c|}{ Conventional insulin injection therapy } \\
\hline $\begin{array}{l}1 \\
2 \\
3 \\
4 \\
5 \\
6\end{array}$ & $\begin{array}{r}57 \\
96 \\
65 \\
6 \\
13 \\
234\end{array}$ & $\begin{array}{r}32 \\
54 \\
94 \\
5 \\
21 \\
232\end{array}$ & $\begin{array}{r}21 \\
83 \\
25 \\
6 \\
12 \\
229\end{array}$ & $\begin{array}{r}19 \\
26 \\
37 \\
10 \\
15 \\
474\end{array}$ & $\begin{array}{r}20 \\
5 \\
7 \\
11 \\
15 \\
459\end{array}$ & $\begin{array}{r}53 \\
64 \\
28 \\
9 \\
8 \\
565\end{array}$ & $\begin{array}{r}25 \\
113 \\
53 \\
13 \\
17 \\
671\end{array}$ & $\begin{array}{r}20 \\
53 \\
37 \\
8 \\
18 \\
760\end{array}$ & $\begin{array}{r}20 \\
52 \\
50 \\
42 \\
20 \\
651\end{array}$ \\
\hline $\begin{array}{l}\text { Geometric mean } \\
\text { SD }\end{array}$ & $\begin{array}{l}43 \\
58\end{array}$ & $\begin{array}{l}40 \\
52\end{array}$ & $\begin{array}{l}30 \\
40\end{array}$ & $\begin{array}{l}34 \\
46\end{array}$ & $\begin{array}{l}19 \\
32\end{array}$ & $\begin{array}{l}40 \\
62\end{array}$ & $\begin{array}{l}53 \\
78\end{array}$ & $\begin{array}{l}40 \\
64\end{array}$ & $\begin{array}{l}55 \\
71\end{array}$ \\
\hline \multicolumn{10}{|c|}{ Continuous subcutaneous insulin infusion } \\
\hline $\begin{array}{r}7 \\
8 \\
9 \\
10 \\
11 \\
12\end{array}$ & $\begin{array}{r}83 \\
10 \\
73 \\
199 \\
29 \\
5\end{array}$ & $\begin{array}{r}109 \\
19 \\
60 \\
96 \\
16 \\
8\end{array}$ & $\begin{array}{r}78 \\
9 \\
48 \\
32 \\
8 \\
52\end{array}$ & $\begin{array}{r}85 \\
3 \\
44 \\
37 \\
17 \\
5\end{array}$ & $\begin{array}{r}24 \\
6 \\
42 \\
37 \\
9 \\
5\end{array}$ & $\begin{array}{r}1123 \\
5 \\
9 \\
21 \\
10 \\
5\end{array}$ & $\begin{array}{r}31 \\
7 \\
18 \\
34 \\
14 \\
4\end{array}$ & $\begin{array}{r}31 \\
9 \\
58 \\
29 \\
35 \\
7\end{array}$ & $\begin{array}{r}17 \\
6 \\
43 \\
15 \\
32 \\
5\end{array}$ \\
\hline $\begin{array}{l}\text { Geometric mean } \\
\text { SD }\end{array}$ & $\begin{array}{l}35 \\
48\end{array}$ & $\begin{array}{l}34 \\
36\end{array}$ & $\begin{array}{l}28 \\
26\end{array}$ & $\begin{array}{l}18 \\
24\end{array}$ & $\begin{array}{l}15 \\
14\end{array}$ & $\begin{array}{l}19 \\
40\end{array}$ & $\begin{array}{l}14 \\
12\end{array}$ & $\begin{array}{l}22 \\
18\end{array}$ & $\begin{array}{l}15 \\
13\end{array}$ \\
\hline
\end{tabular}

infusion group) and -0.51 to $+1.58 \mathrm{ml} / \mathrm{min} / \mathrm{month}$ (controls). The possibility that a change in the slope of the glomerular filtration rate over time in the infusion group might have been missed because of small numbers cannot entirely be excluded but appears unlikely. Table II shows the individual changes in glomerular filtration rate. No change was recorded in two patients (one in each group) during the 24 months studied. Plasma creatinine concentrations remained within the normal range and did not rise significantly in either group throughout the two years of observation (control group: start 94 (SEM 6) $\mu \mathrm{mol} / 1(1 \cdot 1(0 \cdot 07) \mathrm{mg} / 100 \mathrm{ml})$, end $96(6) \mu \mathrm{mol} / \mathrm{l}$ $(1 \cdot 1(0.07) \mathrm{mg} / 100 \mathrm{ml})$; insulin infusion group: start $93(5) \mu \mathrm{mol} / 1(1 \cdot 1$ $(0.06) \mathrm{mg} / 100 \mathrm{ml})$, end $107(11) \mu \mathrm{mol} / \mathrm{l}(1 \cdot 2(0 \cdot 12) \mathrm{mg} / 100 \mathrm{ml}))$.

The mean fractional clearance of albumin - that is, UV/P divided by glomerular filtration rate, where $\mathrm{U}=$ urinary albumin concentration, $\mathrm{P}=$ plasma albumin concentration, and $\mathrm{V}=$ urine flow-was similar in the two groups and not affected by blood glucose control (fig 3). The albumin excretion rate proved to be widely different at baseline among different subjects, ranging from a normal $7 \mu \mathrm{g} / \mathrm{min}$ to $286 \mu \mathrm{g} / \mathrm{min}$. Great variability 
occurred in each patient throughout the study (table III) without a clear pattern of response to treatment changes. In the control group one patient (case 6) with a record of intermittent Albustix positive testing was Albustix positive at recruitment and continued to show persistent and increasing proteinuria. Four were microalbuminuric (albumin excretion rate $>12$ $\mu \mathrm{g} / \mathrm{min}$, the mean plus $2 \mathrm{SD}$ of normal people in our laboratory being 12 $\mu \mathrm{g} / \mathrm{min}$ ) on most occasions. One patient had a normal albumin excretion rate in all but two collections. In the insulin infusion group no patient became persistently proteinuric but four were consistently microalbuminuric, even though on one occasion one patient (case 11) had a normal albumin excretion rate and another (case 7) had a rate well into the clinically proteinuric range. Two patients had a normal albumin excretion rate for most of the time. The mean $\beta_{2}$ microglobulin excretion rate (not shown) was normal and unchanged in both groups throughout the study.

The mean blood pressure for both groups was similar at the start of the run in period and was maintained unchanged in both groups throughout the entire study (insulin infusion group: start 99 (SEM 3), end 93 (2) $\mathrm{mm} \mathrm{Hg}$; control group: start 98 (3), end 92 (2) $\mathrm{mm} \mathrm{Hg}$. At entry to the study there was a significant inverse correlation in all 12 patients between the absolute glomerular filtration rate on the one hand and blood pressure $(r=-0 \cdot 77$; $\mathrm{p}<0.05)$ and fractional clearance of albumin $(\mathrm{r}=-0.66 ; \mathrm{p}<0.05)$ on the other. Blood pressure and fractional clearance of albumin were significantly positively related to each other $(r=0.64 ; p<0.05)$. Glomerular filtration rate did not correlate significantly with plasma glucose or $\mathrm{HbA}_{1}$ value, nor did change in glomerular filtration rate over the 24 month study period correlate significantly with change in any of the other variables. Final glomerular filtration rate still correlated inversely with fractional clearance of albumin.

\section{Discussion}

This study of 12 selected insulin dependent patients disclosed that renal function, as assessed by the glomerular filtration rate, and though still within the normal range, is already declining progressively at the stage of intermittent clinical proteinuria. The rate of fall in glomerular filtration rate $(\approx 0.9 \mathrm{ml} / \mathrm{min} / \mathrm{month})$ is comparable in magnitude with that observed during the later stages of diabetic renal failure, when Albustix positive proteinuria has become persistent. ${ }^{8}$ These observations are at variance with reports that renal function does not deteriorate during several years of intermittent proteinuria. ${ }^{35}$ Assessment of renal function in earlier work, however, was often based on serum creatinine concentrations and considerable loss of glomerular function may go undetected by this method. A significant rise in serum creatinine concentrations occurs late and only when the glomerular filtration rate has been reduced to about half of normal. ${ }^{11}$ Only three of our patients had raised glomerular filtration rates at entry to the study; in two of these the rates fell consistently with time and one remained unchanged. This differs from earlier reports that patients with intermittent proteinuria may sustain a high glomerular filtration rate for several years. ${ }^{5}$ It agrees, however, with a more recent report of the loss of glomerular function and progression to clinical proteinuria over 10 years in insulin dependent diabetic patients with microalbuminuria and a high glomerular filtration rate. ${ }^{12}$ Although on average renal function declined significantly in both groups, in two patients there was no change in glomerular filtration rate during the 24 month study period. Whether they were behaving differently, or perhaps represented an earlier stage of diabetic nephropathy, remains to be seen.

Many of the albumin excretion rates for individual patients in this study lay in the microalbuminuric range, though, on occasions, falling into the normal range or breaking through the threshold to clinical proteinuria. The reasons for this variability in albumin excretion are unknown and we can only speculate about the mechanisms. A major determinant of transcapillary albumin flux is the transglomerular pressure gradient, itself regulated by both local and systemic factors. Fluctuations in this pressure could well determine fluctuations in the albumin excretion rate, especially as the glomerular barriers become decrepit.

Whatever the mechanism, care should be taken not inadvertently to class as microalbuminuric patients who show intermittent clinical proteinuria. This term is best restricted to diabetic patients with supranormal albumin excretion rates who are persistently Albustix test negative and have no record of clinical proteinuria (corresponding roughly to an albumin excretion rate of $200 \mu \mathrm{g} / \mathrm{min}$ or more). A series of previous negative test results over prolonged periods is necessary for confident classification as microalbuminuric to escape the error of including patients with intermittent proteinuria on the basis of short term screening. The inclusion of such intermittently proteinuric patients may partly explain the apparent failure of some groups to reduce microalbuminuria by strict blood glucose control. ${ }^{13}$ Statistically significant and substantial improvement in glycaemic control failed to influence the albumin excretion rate and fractional clearance and had no detectable effect on the rate at which glomerular function was already declining in these patients. This failure was not attributable to a rise in arterial pressure. Even though arterial pressure was inversely related at entry to both glomerular filtration rate and fractional albumin excretion-a finding also reported by others in diabetics with renal abnormalities ${ }^{12}{ }^{14.16}$-it was maintained unchanged throughout the study and changes in glomerular filtration rate did not relate to changes in arterial pressure. This agrees with previous reports. ${ }^{8718}$ Dietary composition remained unaltered and is therefore unlikely to have affected glomerular filtration rate.

Over the relatively short duration of this study clinical proteinuria became persistently positive in one patient. Whether this will be the fate of them all and the rate at which this will occur remain to be established. The time interval between the initial appearance of proteinuria and persistent clinical proteinuria varies considerably in different people. ${ }^{19}$ The reasons for this variability are unknown but eventually almost all intermittently positive patients appear to progress to persistent clinical proteinuria and renal failure. ${ }^{19}$

Intermittent clinical proteinuria therefore represents a late phase of diabetic nephropathy when glomerular function is already declining; its progression appears not to be influenced by intensified metabolic control. The point of "metabolic no return" for the diabetic kidney must therefore lie at an earlier phase in the development of renal disease.

We thank the staff of Peter Bishop metabolic ward and our diabetic patients for their help. Andrea Collins performed the glycosylated haemoglobin estimations and Angela Goodwin provided valuable statistical help. This study was supported in part by Nordisk-UK and the British Diabetic Association.

\section{References}

1 Wilson JL, Root HF, Marble A. Diabetic nephropathy: a clinical syndrome. $N$ Engl f Med 1951;245:513-7.

2 Watkins PJ, Parsons V, Bewick M. Clin Nephrol 1977;7:243-9.

Watkins PJ, Blainey JD, Brewer DB, et al. The natural history of diabetic renal disease. $Q \mathcal{F}$ Med 1972;41:437-56.

4 Mogensen CE. Renal function changes in diabetes. Diabetes 1976;25:872-9.

5 Mogensen CE. Progression of nephropathy in long-term diabetics with proteinuria and effect of initial anti-hypertensive treatment. Scand f Clin Lab Invest 1976;36:383-8.

6 Jeppson I-O, Franzen B, Nilsson KO. Determinations of the glycosvlated haemoglobin fractions epson I-O, Franzen B, Nilsson KO. Determinations of the glycosylated haemoglobin
HbA $_{\text {Ic }}$ in diabetes mellitus by thin-layer electrofocusing. Science Tools 1978;25:69-72.

7 Chantler C, Garnett ES, Parsons V, Veall N. Glomerular filtration rate measurement in man by single injection method using ${ }^{51}$ Cr EDTA. Clin Sci 1969;37:169-80.

8 Viberti GC, Bilous RW, Mackintosh D, Keen H. Monitoring glomerular function in diabetic nephropathy. A prospective study. Am J Med 1983;74:256-64.

9 Pickup JC. ABC of diabetes. Continuous subcutaneous insulin infusion. $\mathrm{Br}$ Med $\mathcal{F}$ 1982;285 49-50.

10 Bending JJ. Starting pump therapy. Diabetic Medicine 1984;1:35-6.

11 Black DAK, Cameron JS. Renal function. In: Brown SS, Mitchell FL, Young DS, eds. Chemical diagnosis of disease. Amsterdam: Elsevier, 1979:453-524.

12 Mogensen CE, Christensen CK. Predicting diabetic nephropathy in insulin-dependent diabetic patients. N Engl F Med 1984;311:89-93.

13 Feldt-Rasmussen B, Mattüesen ER, Deckert T. No effect on kidney function after I year of strict metabolic control in $100 \mathrm{~m}$ patients with micro-albuminuria. Diabetes Research and Clinical Practice 1985; suppl 1:5161.

14 Parving H-H, Andersen AR, Smidt UM, Oxenboll B, Edsberg B, Sandahl Christiansen J. Diabetic nephropathy and arterial hypertension. Diabetologia 1983;24:10-2.

15 Parving H-H, Andersen AR, Smidt UM, Svendsen PAa. Early aggressive antihypertensive treatment reduces the rate of decline in kidney function in diabetic nephropathy. Lancet 1983;i:1175-9.

16 Wiseman M, Viberti G, Mackintosh D, Jarrett RJ, Keen H. Glycaemia, arterial pressure and micro-albuminuria in type 1 (insulin-dependent) diabetes mellitus. Diabetologia 1984;26:401-5.

17 Jones RH, Hayakawa H, Mackay JD, Parsons V, Watkins PJ. Progression of diabetic nephropathy. Lancet 1979;i:1105-6.

18 Parving H-H, Smidt UM, Friisberg B, Bonnevie-Nielsen V, Andersen AR. A prospective study of glomerular filtration rate and arterial pressure in insulin dependent diabetics with diabetic nephropathy. Diabetologia 1981;20:457-61.

19 Ireland JT, Viberti GC, Watkins PJ. The kidney and the urinary tract. In: Keen H, Jarrett J, eds. Complications of diabetes. London: Edward Arnold, 1982:137-78.

(Accepted 27 September 1985) 